\title{
Ocena i prognozowanie stanu pokładowych chemicznych źródel energii elektrycznej
}

\begin{abstract}
W niniejszym artykule określono parametry krytyczne oraz przedstawiono sposoby ich detekcji i oceny $w$ odniesieniu do pokładowych pierwotnych $i$ wtórnych chemicznych źródet energii elektrycznej. Prognozowanie stanu źródet energii jest konieczne w celu umożliwienia wczesnego wykrycia lub uniknięcia uszkodzeń, co postuży do ograniczenia ich skutków i zapewni nieprzerwanq eksploatację pojazdów szynowych.

Do parametrów krytycznych, których stan należy nadzorować $w$ celu utrzymania zdolności ruchowej pojazdu na założonym poziomie, w przypadku chemicznych źródet energii elektrycznej należa:okres użytkowania ogniw galwanicznych, liczba cykli tadowania / rozładowania akumulatorów, przyrost temperatury podczas pracy, napięcie i prad ladowania / rozładowania akumulatorów.
\end{abstract}

\section{Wprowadzenie}

Artykuł powstał w wyniku realizacji projektu rozwojowego pt. "Mikroprocesorowy system diagnostyczny głównych systemów trakcyjnego pojazdu szynowego uwzględniający ocenę bieżącą i prognozowanie stanów" finansowanego przez Ministerstwo Nauki i Szkolnictwa Wyższego (nr projektu N R10 0048 06/2009).

W niniejszym artykule określono parametry krytyczne oraz przedstawiono sposoby ich detekcji i oceny w odniesieniu do pokładowych pierwotnych i wtórnych chemicznych źródeł energii elektrycznej.

Źródła chemiczne pierwotne (ogniwa galwaniczne bez możliwości ponownego ładowania) i wtórne (ogniwa i akumulatory) są istotnymi elementami w pojeździe szynowym, więc wczesne wykrycie lub uniknięcie uszkodzeń posłuży do ograniczenia ich skutków i obniżenia kosztów eksploatacji pojazdu.

\section{Parametry krytyczne}

Do parametrów krytycznych, których stan należy nadzorować w celu utrzymania zdolności ruchowej pojazdu na założonym poziomie, w przypadku pierwotnych i wtórnych źródeł energii elektrycznej należą:

- okres użytkowania ogniw galwanicznych,

- liczba cykli ładowania / rozładowania akumulatorów,

- przyrost temperatury podczas pracy,

- napięcie i prąd ładowania / rozładowania akumulatorów.

\section{Ocena i prognozowanie stanu \\ Okres użytkowania}

Producenci pierwotnych i wtórnych chemicznych źródeł energii elektrycznej określają datę końcową eksploatacji. Należy jej bezwzględnie przestrzegać i po tej dacie wymienić źródło na nowe. Ponadto należy zapewnić właściwe warunki przechowywania i eksploatacji określone przez wytwórcę. Trwałość akumulatorowych ogniw zasadowych osiaga $15 . .18$ lat $[1,2]$.

Jeżeli istnieje taka możliwość, to należy wpisać do pamięci nieulotnej systemu sterowania i diagnostyki pojazdu aktualne daty końcowe eksploatacji dla każdego źródła energii i odpowiednio wcześniej informować użytkownika o konieczności wymiany źródła na nowe.

W przypadku braku wspomnianej możliwości należy postępować według procedur pisemnych, np. kontrolować datę końcową eksploatacji podczas przeglądów okresowych.

\section{Liczba cykli pracy}

Producenci chemicznych wtórnych źródeł energii elektrycznej określają maksymalną liczbę cykli pracy: ładowanie / rozładowanie. Po jej przekroczeniu należy wymienić źródło na nowe.

Jeżeli istnieje taka możliwość, to należy odnotowywać w pamięci nieulotnej systemu sterowania i diagnostyki pojazdu liczbę ładowań i rozładowań. Z odpowiednim wyprzedzeniem należy informować użytkownika o konieczności wymiany źródła na nowe.

W przypadku braku wspomnianej możliwości należy szacować liczbę cykli w celu określenia momentu wymiany źródła.

\section{Przyrost temperatury podczas pracy}

Należy przestrzegać, aby nie przekraczać dozwolonych przez producentów przyrostów temperatury $\mathrm{w}$ źródle energii. Gwarantuje to bezawaryjność eksploatacji źródeł energii.

Jeżeli istnieje taka możliwość, to należy mierzyć temperaturę - w sposób ciagły lub progowy (detekcja przekroczenia wartości progowej). W razie przekroczenia dopuszczalnej temperatury należy przerwać ładowanie (ew. zmniejszyć prąd ładowania / rozładowania). 
W przypadku braku możliwości pomiaru temperatury należy przestrzegać wyznaczonych przez producenta parametrów elektrycznych (napięcie i prąd ładowania; prąd i napięcie końcowe wyładowania).

\section{Napięcie i prąd ladowania / roztadowania}

Należy przestrzegać zaleceń producentów odnośnie wartości i zmienności w czasie napięć i prądów ładowania oraz rozładowania, $\mathrm{z}$ uwzględnieniem korekcji napięcia ładowania $\mathrm{w}$ zależności od temperatury zewnętrznej (absolutne minimum to uwzględnienie pory roku). Przykład takiej zależności pokazano na rysunku 1.

Wytyczne producentów powinny być zaimplementowane $\mathrm{w}$ sterownikach urządzeń ładujących i sterownikach pojazdowych nadzorujących obciążenia źródeł energii.

W razie stwierdzenia, że:

- ładowanie trwa zbyt długo (nie osiaga się wymaganego napięcia końcowego),

- prąd ładowania jest zbyt niski,

- następuje podejrzanie szybki przyrost temperatury w źródle,

- napięcie końcowe rozładowania jest zbyt niskie,

należy niezwłocznie odłączyć źródło energii, poddać je przeglądowi i ew. wymienić.

Producenci wyznaczają również zestaw czynności przeglądowych, które należy wykonywać okresowo podczas przeglądów pojazdów. Przykłady pokazano w tabeli 1 i 2.
Tabela 1

Czynności utrzymaniowe zapobiegawcze i korygujące pokładowej baterii akumulatorów w lokomotywie [2]

\begin{tabular}{|c|c|c|}
\hline \multirow{2}{*}{ Czynność } & \multicolumn{2}{|c|}{ Częstotliwość } \\
\hline & Przebieg & Czas \\
\hline $\begin{array}{l}\text { Wizualna inspekcja ba- } \\
\text { terii i pojemnika na baterię }\end{array}$ & & $\begin{array}{l}\text { co } 160- \\
180 \mathrm{dni}\end{array}$ \\
\hline $\begin{array}{l}\text { Sprawdzenie poziomu } \\
\text { elektrolitu }\end{array}$ & & $\begin{array}{l}\text { co } 160- \\
180 \text { dni }\end{array}$ \\
\hline Pomiar napięcia baterii & & $\begin{array}{l}\text { co } 160- \\
180 \text { dni }\end{array}$ \\
\hline $\begin{array}{l}\text { Dolewanie wody desty- } \\
\text { lowanej }\end{array}$ & & $\begin{array}{l}\text { co } 160- \\
180 \text { dni }\end{array}$ \\
\hline $\begin{array}{l}\text { Czyszczenie baterii, } \\
\text { skrzyni i pojemnika na } \\
\text { baterię }\end{array}$ & & $\begin{array}{l}\operatorname{co} 320- \\
360 \text { dni }\end{array}$ \\
\hline $\begin{array}{l}\text { Pomiar rezystancji izo- } \\
\text { lacji }\end{array}$ & & $\begin{array}{l}\text { co } 320- \\
360 \text { dni }\end{array}$ \\
\hline $\begin{array}{l}\text { Pomiar gęstości elektro- } \\
\text { litu }\end{array}$ & $\begin{array}{l}\text { co } 500.000 \\
\mathrm{~km}\end{array}$ & co 5 lat \\
\hline $\begin{array}{l}\text { Pomiar napięcia każdego } \\
\text { ogniwa baterii }\end{array}$ & $\begin{array}{l}\text { co } 500.000 \\
\mathrm{~km}\end{array}$ & co 5 lat \\
\hline Test pojemności & $\begin{array}{l}\text { co } 500.000 \\
\mathrm{~km}\end{array}$ & co 5 lat \\
\hline Ładowanie renowacyjne & $\begin{array}{l}\text { co } 500.000 \\
\mathrm{~km}\end{array}$ & co 5 lat \\
\hline Wymiana baterii & $\begin{array}{c}\text { co } \\
1.500 .000 \mathrm{~km}\end{array}$ & co 18 lat \\
\hline
\end{tabular}

LADOWANIE 2 STOPNIOWE $Z$ OGRANICZENIEM PRADU IKOMPENSACJA TEMPERATUROWA

- $3 \mathrm{mV} /{ }^{\circ} \mathrm{C}$ NA OGNIWO PRZY $20^{\circ} \mathrm{C}$

DLA BATERII HOPPECKE TYPU FNC MR (72 OGNIWA)

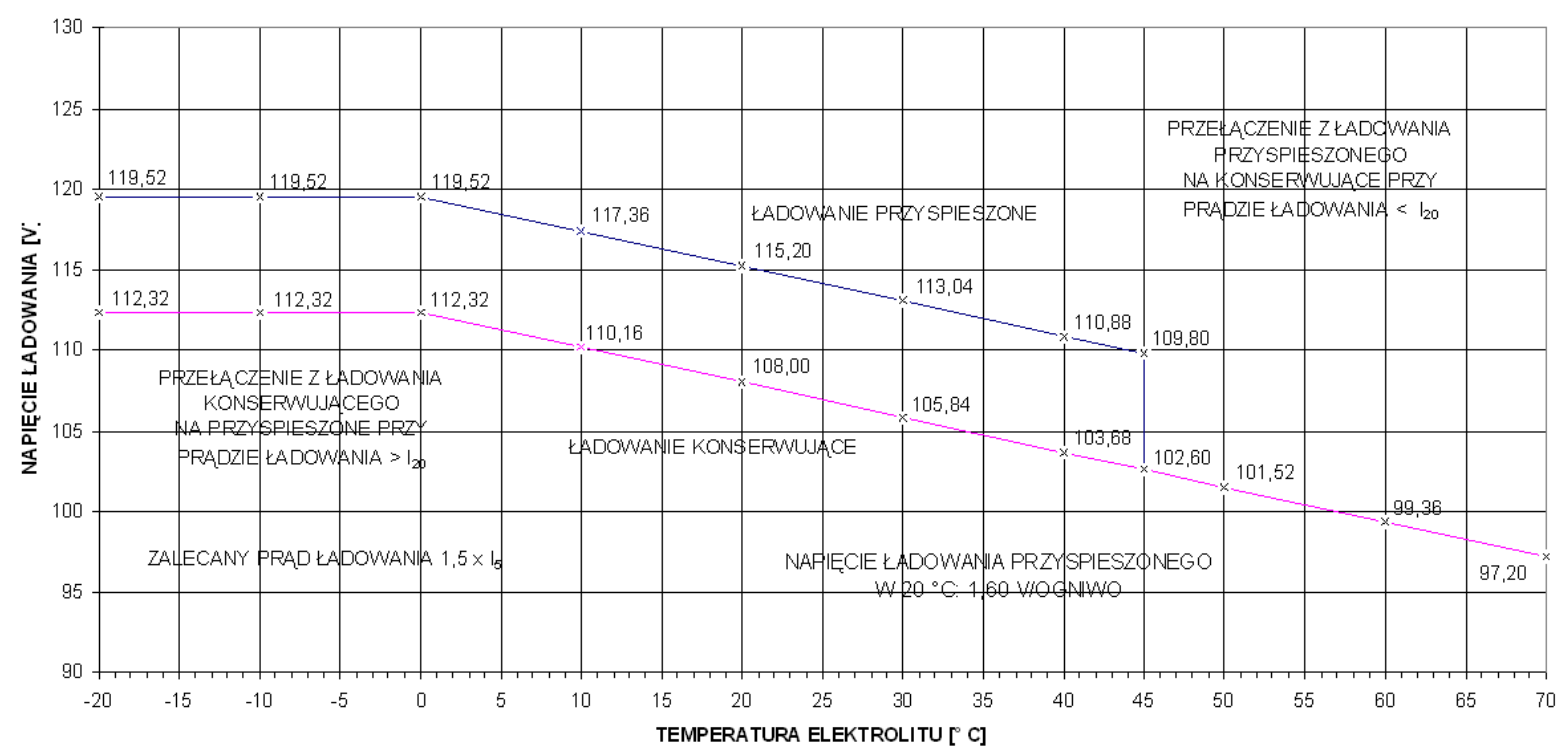

Rys. 1 Zależność napięcia ładowania akumulatorów zasadowych $110 \mathrm{~V}$ od temperatury otoczenia [2] 
Tabela 2

Detekcja stanu i procedura wymiany baterii wewnętrznej w rejestratorze prędkościomierza lokomotywy [3]

11 Opis charakterystycznych usterek metod ich usuwania

\section{Opis charakterystycznych usterek metod ich} usuwania

11.1 Sygnalizacja stanów roboczych (LED)

Dioda pulsuje ciągle na OSTRZEŻENIE!

przemian w kolorach zielonym

/ żóltym:

Urządzenie EFA15 pracuje poprawnie. Kod pulsowania oznacza, że kończy się żywotność baterii buforującej RTC (jeżeli urządzenie jest wyposażone w buforowany baterią zegar RTC).

Do wykonania:

Wymienić baterię RTC lub zwrócić się do naszego serwisu.

13 Wytyczne dotyczace utrzymania $i$ konserwacji

\section{Wytyczne dotyczące utrzymania i konserwacji}

13.4.1 Wymiana baterii

Uwaga

Wymiany baterii może dokonywać tyko

personel, specjalnie przeszkolony przez firme

DEUTA i posiadający odpowiedni certyfikat.

Przed demontażem EFA15 celem dokonania wymiany baterii należy zapewnić miejsce pracy. zabezpieczone pod kątem ladunków elektrostatycznych (przewodząca podkładka. opaska uziemiająca na rękę itp,).

Wskazówka

$$
\begin{aligned}
& \text { Następna data wymiany baterii znajduje się na } \\
& \text { naklejce usytuowanej na frontowej czẹsci } \\
& \text { urzadzenia. } \\
& \text { Baterię należy wymieniaćco } 3 \text { lata. }
\end{aligned}
$$

Przy wymianie baterii należy odpowiednio zaktualizować naklejkẹ.

1. Zdemontować EFA15 z nośnika podzespo Пów, w tym celu należy poluzować śruby pokazane na rysunku.

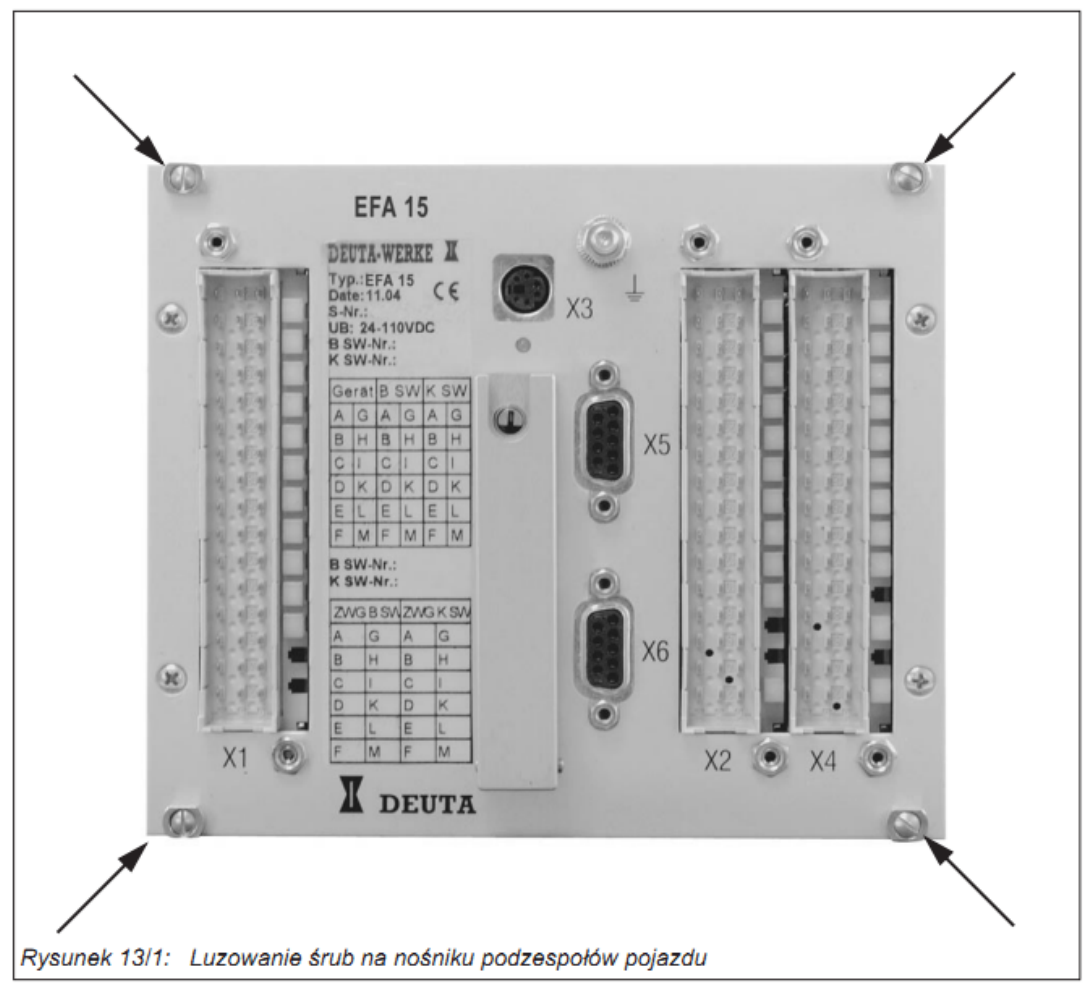

2. Wymontowane urządzenieEFA15 należy położyć na uziemionym podłożu. 
ciąg dalszy Tabeli 2

3. Celem zdjęcia p'yty czo'owej należy poluzować śruby pokazane na poniższym rysunku:

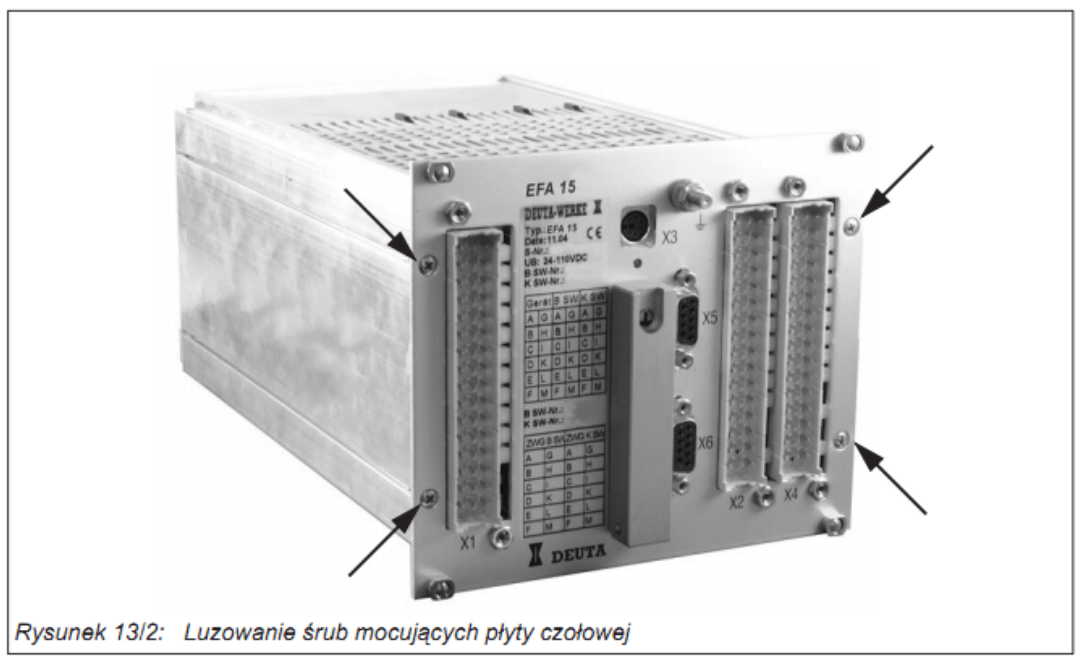

4. Wyciagnąć płytę czołowa wraz z modułem MPU z wnęki korpusu i położyć na uziemionym podłożu. (przy wymianie baterii moduł MPU nie jest potrzebny).

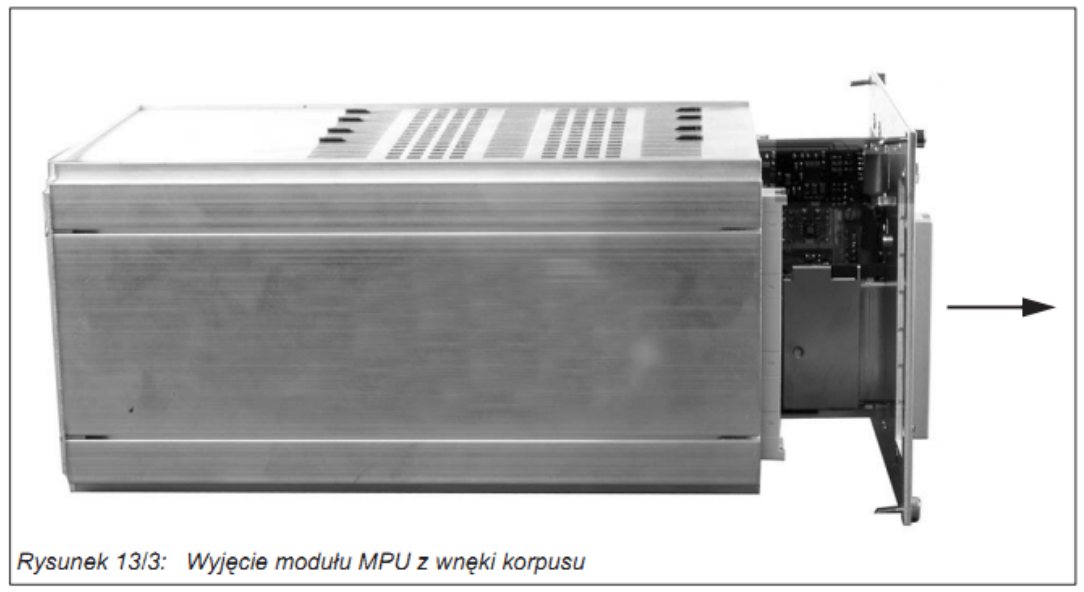

5. Teraz wyciagnąć moduł IFU z wnẹki korpusu.

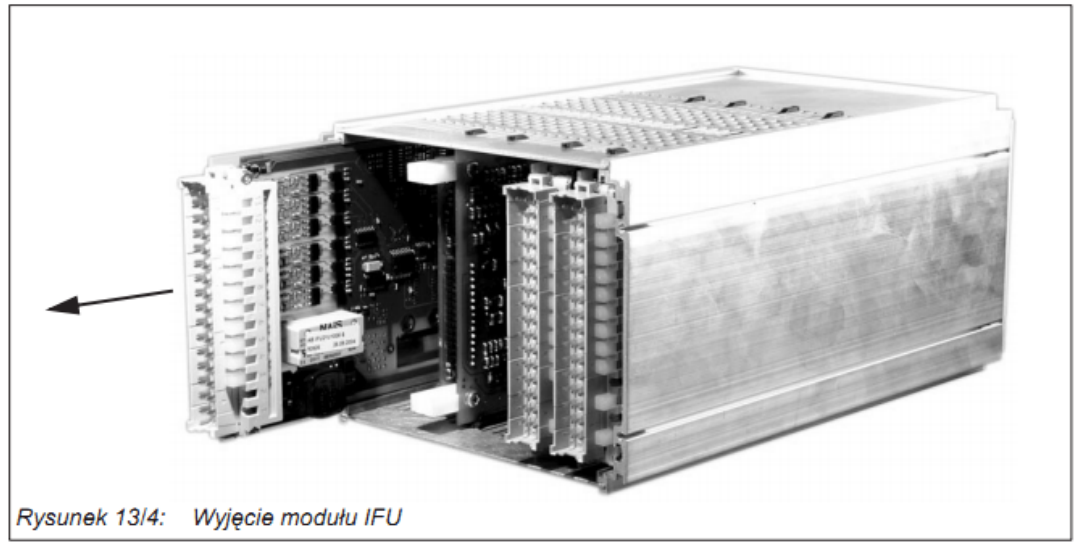

6. Wyjety moduł IFU położyć przed sobą na uziemionym podłożu 


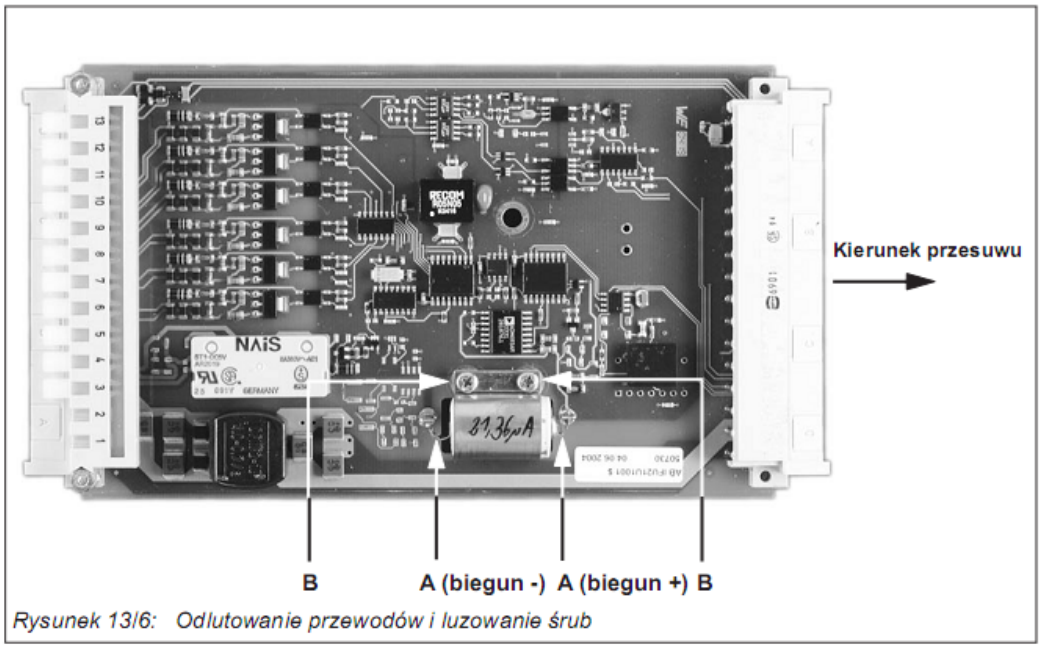

8. Wyjąć obsadę baterii i wymienić baterię na nową. Zwrócić przy tym uwagẹ na biegunowość baterii! Zobacz rozdz. 13.5

9. Włożyćc obsadę baterii z powrotem. Na początek lekko dociagnąc śruby (B)

10. Przylutować przewody przyłączeniowe (A) baterii. Teraz mocno dociagnąc śruby obsady baterii (B).

13.5 Części zamienne

Bateria litowa z końcówkami lutowniczymi płaskimi

Nr EPD: $\quad 37700331$

$\mathrm{Nr}$ magazynowy: Zu188

SAFT: $\quad$ LS14250

\section{Podsumowanie}

Prognozowanie stanu pokładowych źródeł energii jest konieczne w celu umożliwienia wczesnego wykrycia lub uniknięcia uszkodzeń, co posłuży do ograniczenia ich skutków i zapewni nieprzerwaną eksploatację pojazdów szynowych.

Kryteria dotyczące wtórnych źródeł energii można $\mathrm{z}$ powodzeniem zastosować do kondensatorowych zasobników energii. Trwałość współczesnych superkondensatorów wynosi ponad $10^{6}$ pełnych cykli ładowanie / rozładowanie, co przy założeniu $10^{4}$ cykli miesięcznie, zapewnia ponad 8 lat eksploatacji [4].

\section{Literatura}

[1] Akumulator niklowo-kadmowy MRX. Wysokoenergetyczny kompaktowy akumulator zasilania rezerwowego do zastosowań $w$ kolejnictwie, SAFT, grudzień 2009.

[2] Bateria niklowo-kadmowa $72 \times$ FNC 142 MR do zmodernizowanej lokomotywy ET-22. Dokumentacja Techniczno-ruchowa, HOPPECKE Baterie Polska, 2004.

[3] Elektroniczne urzadzenie do rejestracji danych jazdy EFA15. Dokumentacja Techniczno-ruchowa, DeutaWerke, 2008.

[4] Kobos W.: Trakcyjny napęd asynchroniczny o podwyższonej sprawności energetycznej z wykorzystaniem pojemnościowego zasobnika energii, Pojazdy Szynowe nr 4/2009, str.30-34. 